\title{
The Effects of Creative Drama on the Learning of Job Interviewing Skills for Vocational College Students in Sabah
}

\author{
Juliza Binti Yusof1, Maslawati Binti Mohamad² \\ ${ }^{1}$ Beaufort Vocational College, Beaufort, USA \\ ${ }^{2}$ Universiti Kebangsaan Malaysia, Bandar Baru Bangi, Malaysia \\ Email: julizayusof@gmail.com
}

How to cite this paper: Yusof, J. B., \& Mohamad, M. B. (2018). The Effects of Creative Drama on the Learning of Job Interviewing Skills for Vocational College Students in Sabah. Creative Education, 9, 2059-2069.

https://doi.org/10.4236/ce.2018.913149

Received: September 11, 2018

Accepted: October 23, 2018

Published: October 26, 2018

Copyright (๑) 2018 by authors and Scientific Research Publishing Inc. This work is licensed under the Creative Commons Attribution International License (CC BY 4.0).

http://creativecommons.org/licenses/by/4.0/

\begin{abstract}
Answering interview questions in English is often perceived as a big challenge by potential employees in Malaysia. The researchers have found creative drama effective to students as it suits students' multiple intelligences $(1.1$ \& 1.2). By integrating creative drama in the teaching of job interviewing skills, the educators hoped that this intervention could help improve vocational college students' job interviewing skills. Thus, this study was embarked to investigate the vocational college students' perception on the effects of creative drama on their learning of job interviewing skills. The research instruments were focus group interview, field notes and reflective notes. The participants were three student performers and three student audiences of the creative drama from Refrigerator and Air-Conditioning course. The data were analysed by applying thematic analysis. The main findings are: participants found that creative drama as one of the most effective activity to learn job interviewing skills. Creative drama enhances the participants' confidence level and communication skills before attending the real job interview. It is hoped that this study offers insights to educators in integrating creative drama in their English for Workplace Purposes lessons.
\end{abstract}

\section{Keywords}

Effects, Creative Drama, Job Interviewing Skills, Vocational College Students, Intervention

\section{Introduction}

The status of English language is dominant in the world even in a foreign setting like Japan (Shiozawa \& Donnery, 2017). In the second language setting like 
Malaysia, the importance of English language is even more as it is emphasised in the current National Education Blueprint, to produce proficient children at Bahasa Malaysia, English language and an additional language.

The importance of English language is not solely confined to school setting. At the workplace, communication in English language is one of the skills sought by employers. Malaysian Employers Federation (MEF) reported that there were 200,000 unemployed graduates in Malaysia in 2016 excluding the ones that have just completed their Sijil Pelajaran Malaysia (SPM), diplomas and certificate programmes (Balakrishnan, 2017). Poor attitude, lack of English proficiency, and poor communication skills are the main reasons why fresh graduates were not accepted by the potential employers. Interestingly, Nor Zahidi (2017) argued that compared to other nationalities, Malaysians are more favourable to be employed because of English as the second language status. To reiterate, in her study, employees' proficiency in English language is the top priority by majority of employers. Potential employees' skills of work they are applying come second after communication skills because training programmes are provided to raise their employees' competences.

Due to the importance of job interviewing skills among students of Technical and Vocational education, the researchers had introduced creative drama to enlighten them on how to perform well in job interviews. Thus, the aim of this paper is to explore the effects of creative drama on the learning of job interviewing skills to vocational college students in Sabah.

\section{Literature Review}

The $21^{\text {st }}$ century learning method (PAK-21) has been actively promoted nowadays. The aforesaid method is embedded mainly in the seventh shift from the National Education Blueprint. It aims to transform the education system from the conventional setting to a more dynamic and digital method whereby the latest technology is highly recommended. Despite the method used in this study is pantomime, a type of creative drama which has been introduced years back, the idea of conducting it is derived from Information and Communication Technologies, (ICT) specifically from an edutainment social enterprise, Englishjer. Englishjer's objective is to promote a better setting of learning English in Malaysia through creative ideas and is accessible at social media such as Youtube, Instagram, Facebook and Twitter (Abdul Qayyum, 2013). The creative drama was improvised from one of Englishjer's video titled 'Interview Tips and Tricks' (Abdul Qayyum, 2015). As a result, this present study is a combination of both traditional and digital ways of teaching as promoted by Faridah et al. (2015), creative drama could promote effective collaboration among students which is described as one of the characteristics of $21^{\text {st }}$ century learners. There are some underpinning theories related to creative drama namely Howard Gardner's multiple intelligences, Vygotsky's Zone Proximal Development and Krashen's Affective Filters. 


\subsection{Howard Gardner's Multiple Intelligences}

Howard Gardner outlined multiple intelligences possessed by learners. In this present study, a few of the English club members were linguistically inclined and they guided the lower to mediocre proficiency students who were kinaesthetic learners for the creative drama. This is corroborated by Li and Lam (2013) who found that the diversified levels of students improves their cognitive, psychological and social performance, hence offers an effective way to solve the problem of individual differences.

\subsection{Krashen's Affective Filter Hypothesis}

According to Shand (2008), learners' anxiety can be reduced when drama is utilised in a classroom. She added that by using drama, learners' self-esteem and motivation to learn English language can be increased too. Likewise, Fleming (2011) stated that drama provides motivation. Even in English as a foreign language setting, drama-based English is capable of making learners relaxed and confident (Shand, 2008; Coleman, 2005). Similarly, Atas (2014) found that the intervention of drama in learning English does help to lower the speaking anxiety of learners. A recent study conducted by Nath, Maslawati and Hamidah (2017) also corroborated this finding. They studied about movies that are akin to creative drama and they found that movies do reduce learners' specifically the low achievers' affective filter in learning English language. Their idea is in the same vein with Krashen's affective filter hypothesis which explains that students' psychological factors such as anxiety and emotional state need to be minimised in order to learn English successfully. In this study, the respondents did not feel too apprehensive with their presence of peers while performing the creative drama. They also felt relieved as the creative drama was meant to be just a performance, not a competition.

\subsection{Vygotsky's Social Constructivism Theory}

Besides optimizing multiple intelligences and reducing affective filter, Johnson and Johnson (1999) found that cooperation is the most positive way to achieve learning outcome. When a drama is performed it definitely needs cooperation and teamwork among the performers. Cooperative learning also falls under social constructivism theory as proposed by Vygotsky. Working in a team means everyone is accountable in completing a task ( $\mathrm{Li} \& \mathrm{Lam}, 2013$ ). In cooperative learning group, students optimise their own learning and their group members' (Johnson \& Johnson, 1999).

\subsection{Past Studies}

Generally, there are many past researches could be found regarding the beneficial opportunities of drama at large in the teaching and learning of English. McCaslin (2006) believes that dramatization helps English language learners to learn English in a fun yet beneficial manner. Pantomime, a type of creative 
drama is under drama-based pedagogy and it does help to improve learners with and without disability to improve speaking, reading, writing skills as well as perspective taking 3.1 (Anderson et al., 2017). Sri Puji (2017) conducted a research on what makes students demotivated to learn English and her findings reported that the respondents feel motivated if the activities are engaging and enjoyable such as drama or role-play. This is also aligned with Güzel (2017) who found that script-based and improvisational drama helps learners improve their oral proficiencies, decrease their negative thoughts, lowered their stress, anxiety and inhibition levels, and increased their motivations.

Locally, Faridah et al. (2016) conducted a study which used project work to develop workplace awareness among UKM students. It is found that the project work has exposed students to the importance of having relevant skills and qualities at the workplace. Despite the richness of past researches in drama and job interview, a study involved vocational college students in Sabah is scarce. This has encouraged the researchers to investigate in this area and fill the research gap. Hence, in this study, the effects of creative drama on the learning of job interviewing skills to students in Beaufort Vocational College are explored.

\section{Methodology}

\subsection{Research Design}

A case study was employed to conduct this qualitative research. Strauss and Corbin (1990) define qualitative study in general as "any kind of research that produces findings not arrived at by means of statistical procedures or other means of quantification" (p. 17).

The rationale of conducting a case study is it represents a typical case of a large institution (Yin, 2003). Case study illustrates a deep exploration of a bounded system, the creative drama in this case, based on extensive data collection (Creswell, 2012).

\subsection{Research Instruments}

The research instruments of the study are focus group interview, students' reflective notes and field notes. Interview was chosen as it is targeted directly on the case study topic and insightful (Yin, 2003). Reflective notes was used because it helps to complement what the respondents may have left during the interview session. Field notes was chosen as it covers information in the real time and is contextual (Yin, 2003).

\subsection{Population and Sample of the Study}

Purposive sampling means researchers purposely choose respondents who meet the required criteria (Creswell, 2012). Purposive sampling was chosen in this study because 1.3. the researchers aim to improve her own students from Refrigerator and Air-Conditioning course. The respondents were six third year Beaufort Vocational College students of Refrigerator and Air-Conditioning 
course. The participants belong to two different parties, three of them were the performers of the creative drama and the remaining three were the audience.

The three student performers were chosen as they were among the nine student performers on stage and the researcher also taught them in Refrigerator and Air-Conditioning class while the remaining three student audiences were chosen as they represented the good, mediocre and poor students of Refrigerator and Air-Conditioning course (Table 1).

\subsection{Data Collection and Analysis}

This study employed three data collection methods which are field notes, focus group interview, and reflective notes. Field notes were collected after each event happened. The events are categorized into three main phases which are pre, while and post. The pre phase refers to events happened before the performance of the creative drama, namely the audition, the practice and the rehearsal. The while phase refers to the performance of the creative drama and the post phase are the events which happened after the performance. Post-mortem, focus group interview and reflective notes were conducted during the post phase. The data from the focus group interview and reflective notes were collected after the transcription was done by the researcher.

The data analysis was done in three stages. They are data transcribing, data coding and data analysis. After the interview transcription was done, the researchers coded and categorized the data. Finally, the emerging themes related to the data were identified and represented.

\subsection{Validity and Reliability}

To increase validity and reliability in this study, the researchers applied triangulation which is according to Creswell (2012) the process of corroborating

Table 1. Participants' profile.

\begin{tabular}{|c|c|c|c|c|c|}
\hline PSEUDONYM & AGE & COURSE & $\begin{array}{c}\text { LANGUAGE } \\
\text { ABILITY }\end{array}$ & INTEREST & AMBITION \\
\hline $\begin{array}{c}\text { ZAFRI } \\
\text { (Student Performer) }\end{array}$ & 18 & $\begin{array}{l}\text { Refrigerator and } \\
\text { Air-Conditioning }\end{array}$ & Poor & Reading & Teacher \\
\hline $\begin{array}{l}\text { IBRAHIM (Student } \\
\text { Performer) }\end{array}$ & 18 & $\begin{array}{l}\text { Refrigerator and } \\
\text { Air-Conditioning }\end{array}$ & Good & Fishing & Engineer \\
\hline $\begin{array}{c}\text { AZLAN } \\
\text { (Student Performer) }\end{array}$ & 18 & $\begin{array}{l}\text { Refrigerator and } \\
\text { Air-Conditioning }\end{array}$ & Good & $\begin{array}{l}\text { Playing } \\
\text { Football }\end{array}$ & Football Player \\
\hline $\begin{array}{c}\text { ARNOLD } \\
\text { (Student Audience) }\end{array}$ & 18 & $\begin{array}{l}\text { Refrigerator and } \\
\text { Air-Conditioning }\end{array}$ & Good & $\begin{array}{c}\text { Playing } \\
\text { Badminton }\end{array}$ & Businessman \\
\hline $\begin{array}{c}\text { DYLAN } \\
\text { (Student Audience) }\end{array}$ & 18 & $\begin{array}{l}\text { Refrigerator and } \\
\text { Air-Conditioning }\end{array}$ & Average & $\begin{array}{c}\text { Playing } \\
\text { Badminton }\end{array}$ & Travel Agent \\
\hline $\begin{array}{c}\text { NICK } \\
\text { (Student Audience) }\end{array}$ & 18 & $\begin{array}{l}\text { Refrigerator and } \\
\text { Air-Conditioning }\end{array}$ & Poor & $\begin{array}{c}\text { Training } \\
\text { Taekwondo }\end{array}$ & CEO \\
\hline
\end{tabular}


evidence from different individuals, types of data, or methods or data collection. Additionally, the semi-structured interview questions for the focus group interview was reviewed by an expert, and the transcription of the findings were returned to the respondents for verification. Measures to comply with research ethical conduct were also taken. The respondents were explained that their participation is voluntary, they signed informed consent form prior the focus group interview and their confidentiality is protected.

\section{Findings and Discussion}

The findings and discussion are explained by answering the research questions of the study. (1.4) The research questions (4.1 until 4.3) were proposed due to the difficulty of teaching job interviewing skills to students. Prior to creative drama, one of the researchers had tried teaching job interviewing skills to her students by showing a video explaining some relevant questions with answers and also by asking her students to present a role-play. However, both of the methods used were not very successful.

Hence, the research questions in this study are:

1) "How do the performers experience and perceive creative drama in learning job interviewing skills?"

2) "How do the audience experience and perceive creative drama in learning job interviewing skills?"

3) "To what extend creative drama is effective in moulding students' job interviewing skills to equip them for the real job interview?"

The research questions were answered via the research instruments namely the focus group interview, reflective notes or field notes. The respondents' answers are categorised into themes which are stated in bold:

\subsection{Research Question 1: "How Do the Performers Perceive Creative Drama in Learning Job Interviewing Skills?"}

This research question is answered by observing students' responses before they were asked to perform the creative drama.

1) Creative drama was unfavourable before the performance

"Oh, no, no, no,... not me, please" (FieldNotes, before the audition).

When the researcher asked her students to act on stage, everyone refused and it was very difficult for her to find volunteers. Only a student, Steven volunteered to be the voicer behind the stage. At last, the researcher chose the actors and voicers by herself despite the students' initial reluctance.

2) Students did not have self-confidence

"Teacher, I think you should choose Syazwani or those from Tourism class. They are good at English." (FieldNotes, before the audition).

The researchers discovered that the respondents' reluctance was due to their low confidence level. They regarded their English proficiency level as not at par with their peers from other classes. 
a) "How do the performers experience creative drama in learning job interviewing skills?"

This research question is answered after the creative drama was presented.

3) Creative drama helps students to gain new experience and reduce fear

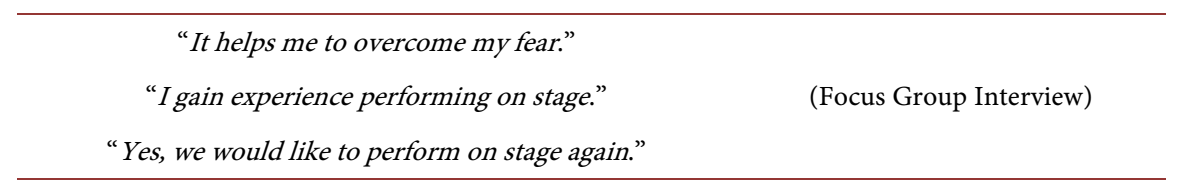

Two of the student performers never presented or performed on stage before. This was their very first time. Despite having no experience before, they enjoyed performing the creative drama and hoped to perform on stage again. This is in contrast with their feedback before they performed the creative drama.

4) Poor students learnt from the good students.

"We also practised at the hostel. Zafri is a fast learner." (FieldNotes, before the performance).

Before the creative drama was performed, Steven came to the researcher to request having the last practice. He added that they practised at their hostel and as the voicer of Zafri, he taught Zafri on how to act well. Zafri learnt from the More Knowledgeable Other, Steven as proposed by Vygotsky, the key proponent of socio constructivist theory. Zafri could not possibly perform by himself due to his low level language proficiency but his Zone of Proximal Development (ZPD) was extended with the help of his peers like Steven.

In a pantomime performance, when a student does not have a good command of language, he or she can cover it up if he or she is capable of acting. Audience may be deceived when they think the voice comes from the actor or actress himself or herself. Similarly, a student who is good at acting may feel appreciated when he or she gives his or her voice to the actor or actress who acted on stage (Carels, 1981).

5) Cooperation among members were inculcated.

"Our friendship gets better." (Focus Group Interview).

"I like it when the voicer and the actor is different because we can work together." (Reflective notes).

"We worked as a team." (Reflective notes).

Creative drama manages students to be responsible and cooperative besides the main objective which is to teach them English language. During the focus group interview, they commented that the bond among them was stronger after the performance as they had spent time together to practise and make the performance a success. The performers always reminded the voicers to give cue to the flash cards bringers so that the show went smoothly. Additionally, the voicers needed to see the actors' action on stage to ensure synchronization. This finding is line with Li and Lam (2013), and Johnson \& Johnson (1999) who promote cooperative learning. 
The respondents also wrote in their reflective note saying that they prefer pantomime to conventional drama because the former involves more people and thus makes them more cooperative. Therefore, the more people are involved, the more learners' potential are unleashed and ultimately knowledge is disseminated more effectively.

6) Job interviewing skills is disseminated effectively.

"From the audience's applause and overwhelming responses, we know that the audience got the message (job interviewing skills). At first, they were quiet but they started to understand (the creative drama) the moment they said 'Ohh..."' (FieldNotes, before the Focus Group Interview).

This excerpt was expressed by the main student performer when the researcher showed the video of the performed creative drama, just before the researcher conducted the focus group interview. From the respondent's answer, the researcher is relieved that the job interviewing skills managed to be disseminated through performing a creative drama. As stated by Kao and O' Neill (1998), the atmosphere of drama performance was very relaxed resulting the performers and the audience to learn easily.

\subsection{Research Question 2: "How Do the Audience Experience and Perceive Creative Drama in Learning Job Interviewing Skills?"}

The audience's experience and perception are mixed as the distinction between experience and perception is not apparent. They were spectators and were not involved in the creative drama.

1) Creative drama helps students to boost their self-confidence

During the focus group interview, the respondents were asked on their preference to perform on stage like their classmates did. They answered,

"Maybe... it can help me improve my confidence"

"Learn to... brave face of all people (be brave facing all people)"

"Yes. Because we can know how to perform on stage"

The respondents' feedback is parallel with Atas (2014), Fleming (2011), Shand (2008) and Coleman's (2005) who found that drama presentation helps to improve the learners' self-confidence.

2) The audience were oblivious to the process of the creative drama as the plot was focused more

When they were asked on the possible improvement on the presented creative drama, one of them answered maybe the actor's voice can be improved. Little did they know that the voice was somebody else's.

Researcher: The actors did not talk. Another person did. There was a voice behind the stage.

Respondents: Oooohhh...

3) Video precedes creative drama

(Focus Group Interview)

The researcher found it insightful when one of the respondents stated the creative drama video helps students to learn job interviewing skills. This is because, 
the audience may forget the creative drama when the performance was over.

"The most effective way to learn interviewing skills is from the video (drama). because it can help us to improve everything that we need and sometimes we can repeat (replay) again... (when) we forget"

(Focus Group Interview).

\subsection{Research Question 3: To What Extend Creative Drama Is Effective in Moulding Students' Job Interviewing Skills to Equip Them for the Real Job Interview?}

(1.5) Job interviewing skills has an array of definitions. The researchers follow the definition as found by NC4IR-TVET organising chairman Associate Professor Dr Mohamad Sattar Rasul which also suits the skills needed to face the fourth Industrial Revolution. They are learning skills (self-directed learning, cross discipline, digital skills), thinking skills (creative, resilience, inquisitive, problem solving) and soft skills (ethics, communication) (Zulita, 2018). This research focuses on soft skills which centrals on students' ethics and communication.

1) Creative drama enhances students' speaking skills

In drama, the language that arises is "fluent, purposeful and generative because it is embedded in context” (Kao \& O’Neill, 1998: p. 4).

\footnotetext{
"What I learn is... how to communicate correctly to interviewer"

"It helps me to communicate confidently with the interviewers"

Focus Group Interview
}

Both of the student performers and the student audience agreed that they learnt communication skills especially during job interview from the creative drama.

2) Students' ethics are harnessed

The researchers noticed that their students were more disciplined when they were involved in the creative drama. Presumably, when more time was spent with them, the rapport gets better and thus, their manners improved.

After the rehearsal, the main actor, though was not a proficient student apologised when he thought he did not perform well. He expressed sincerely, " $P m$ sorry if I disappointed you, teacher". Another student performer was afraid if the researchers were angry when the creative drama was not successfully performed. He claimed, "In the beginning we made a mistake. We taught you were angry".

During the post mortem session, relatively all of the student performers were elated. One of them stated "You made us happy, teacher. Thank you."

When the researcher asked three of the student performers to be the respondents of the focus group interview, they were ever ready. One of them highlighted, "If teacher needs any help, just ask us". Similarly, the student audience were looking forward to contributing and giving their best. They thanked the researcher when the interview was conducted. 


\section{Conclusion and Implication}

As discussed earlier in the introduction, employers in Malaysia have expressed their dissatisfaction with the fresh graduates' ineptness at the workplace. Therefore, this study attempts to harness one of the important skills needed at the workplace, job interviewing skills or specifically communication skills in English language among vocational college students.

In vocational college, the syllabus of English language subject is not from KSSM. Vocational college students learn General English and English for Specific Purposes in the SVM (certificate) year. In the diploma year, they learn English for Communication. To date, lecturers are given Written Instructional Material, WIM to teach English for Communication course but only an optional workbook to teach General English and English for Specific Purposes. In this study, creative drama can be a guide for English lecturers to teach job interviewing skills to students, especially SVM students so that they have early exposure and could prepare for English for Communication course which explores further on resume writing and mock-job interview.

It is hoped that students, vocational students in particular are well-equipped with the job interview process and possessed both the soft and hard skills necessitated by the potential employers. As much they are needed in the industry, it is a dire need for them to be groomed and meet the government's expectation. In general, this study has reiterated that creative drama really helps students to learn English. (1.6) Creative drama, though may not be the sole contributor, has left some positive effects on the learning of job interviewing skills to vocational college students in Sabah. Therefore, it is important for teachers to try integrating drama in their lesson as it can benefits the learners and indirectly helps to meet the aims in the National Education Blueprint.

\section{Conflicts of Interest}

The authors declare no conflicts of interest regarding the publication of this paper.

\section{References}

Abdul Qayyum, J. (2013). About Englishjer. https://englishjer.co/whodis/

Abdul Qayyum, J. (2015). Interview Tips and Tricks. Video. Kuala Lumpur: University of Malaya.

Anderson, A., Lee, B. K., \& Brown, M. R. (2017). Promoting Literacy and Language Learning in Special Education through Drama-Based Pedagogies. VSA Intersections. Arts and, 111.

Atas, M. (2014). The Reduction of Speaking Anxiety in EFL Learners through Drama Techniques. Procedia-Social and Behavioral Sciences, 176, 961-969.

Balakrishnan, N. (2017). Malaysian Fresh Grads Can't Get Jobs because They Have Attitude Problems. 10th February.

https://says.com/my/news/malaysian-fresh-grads-can-t-get-jobs-because-of-their-attitu $\underline{\mathrm{de}}$ 
Carels, P. E. (1981). Pantomime in the Foreign Language Classroom. Foreign Language Annals, 14, 407-111. https://doi.org/10.1111/j.1944-9720.1981.tb01660.x

Creswell, J. W. (2012). Educational Research. Planning, Conducting and Evaluating Quantitative and Qualitative Research. USA: Pearson.

Faridah, M., Maslawati, M., Norlaila, M., Rozmel A. L., \& Maryam, M. A. (2015). Incorporating Computer-Mediated Communication in Project Work. International Education Studies, 8, 150.

Faridah, M., Maslawati, M., Sithaletchemy, K., \& Wahiza, W. (2016). Developing Workplace Awareness through Project Work. Creative Education, 7, 701-711.

https://doi.org/10.4236/ce.2016.74074

Fleming, M. (2011). Starting Drama Teaching (4th ed.). London: Routledge. https://doi.org/10.4324/9780203818008

Güzel, M. Ç. (2017). Developing Oral Proficiency and Motivation through Script-Based and Improvisational Drama.

Johnson, D. W., \&Johnson, R. T. (1999). Making Cooperative Learning Work. Theory into Practice, 38, 67-73. https://doi.org/10.1080/00405849909543834

Kao, S. M., \& O’Neill, C. (1998). Words into Worlds. Learning a Second Language through Process Drama. Santa Barbara, CA: Greenwood Publishing Group.

Li, M. P., \& Lam, B. H. (2013). The Active Classroom. Hong Kong: The Hong Kong Institute of Education.

McCaslin, N. (2006). Creative Drama in the Classroom and Beyond. Boston: Pearson Education.

Nath, P. R., Maslawati, M., \& Hamidah, Y. (2017). The Effects of Movies on the Affective Filter and English Acquisition of Low-Achieving English Learners. Creative Education, 8, 1357-1378. https://doi.org/10.4236/ce.2017.88096

Nor Zahidi, A. (2017). My Say: Making Graduates More Employable. The Edge Malaysia Weekly. http://www.theedgemarkets.com/article/my-say-making-graduates-more-employable

Shand, J. W. (2008). The Use of Drama to Reduce Anxiety and Increase Confidence and Motivations towards Speaking English with Two Groups of English Language Learners. Tucson, AR: The University of Arizona.

Shiozawa, Y., \& Donnery, E. (2017). Overcoming Shyness: Promoting Leadership and Communication through English Drama Camp in Japan. Scenario, XI, 15-31.

Sri Puji, A. (2017). What Demotivates High School Students to Learn English? Proceedings of ISELT FBS Universitas Negeri Padang, 5, 311-319.

Strauss, A., \& Corbin, J. (1990). Basics of Qualitative Research: Grounded Theory Procedures and Techniques. Newbury Park, CA: Sage Publications, Inc.

Yin, R. K. (2003). Case Study Research: Design and Methods. Thousand Oaks, CA: Sage Publications, Inc.

Zulita, M. (2018). Producing Highly Skilled Workforce for the 4IR. New Straits Times, 3 Jan.

https://www1.nst.com.my/education/2018/01/320969/producing-highly-skilled-workfo $\underline{\text { rce-4ir }}$ 